\title{
Pretreatment techniques used in biogas production from grass
}

Cristina Rodriguez a, Abed Alaswad a, ${ }^{\star}$, K. Y. Benyounis ${ }^{b}$, Abdul G. Olabi a

a School of Engineering and Computing, Institute of Engineering and Energy Technologies, University of the West of Scotland, Paisley, PA1 2BE, United Kingdom.

B: School of Mechanical and Manufacturing Engineering, Dublin City University, Dublin, Ireland.

* Corresponding author. Tel.: +44 1418483977

E-mail addresses: cristina.rodriguez@uws.ac.uk (C. Rodriguez), abed.alaswad@uws.ac.uk (A.

Alaswad), timothy.prescott@uws.ac.uk (T. Prescott), abdul.olabi@uws.ac.uk (A. G. Olabi)

\section{Abstract}

Grass is being considered as a potential feedstock for biogas production, due to its low water consumption compared to other crops, and the fact that it can be cultivated in non-arable lands, avoiding the direct competition with food crops. However, biogas production is limited by the characteristics of the feedstock; in particular its complex lignocellulosic structure. Hence, different pretreatment methods are being investigated for grass structure disruption before undergoing the anaerobic digestion process. The aim of this paper is to review current knowledge on pretreatment techniques used for grassland biomass. Pretreatment techniques were categorized into mechanical, microwave, thermal, chemical and biological groups. The effect of the application of each studied methods on the biogas yield and on the energy balance is discussed. A further comparison between the covered techniques was revealed.

Keywords: biogas; grass; pretreatment; anaerobic digestion; renewable energy.

\section{Introduction}

Grasslands play an important role in global agriculture, covering around the $26 \%$ of world's total land area (2009) and the $78 \%$ of the Scotland's agricultural area (2013). Grasses are the main plant species in verges along roads, railways and on river dikes, for that reason the hectares of grassland available are difficult to quantify. Besides its role as basic nutrient for herbivores and ruminants, grassland has a key role in the prevention of erosion, the immobilisation of leaching minerals and as carbon storage, helps in the regularization of water regimes and in the purification of pesticides and fertilizers. Also serve to furnish a habitat for wildlife, both flora and fauna and contribute to the attractiveness of the landscape [1-4]. 
In recent years considerations on grassland use for bioenergy have increased considerably, mainly for biogas production and as solid fuel for combustion [5]. A well as for biogas production, grasses can be used in future for the production of lignocellulosic bioethanol, synthetic natural gas or synthetic biofuels. The main benefits of using grass for bioenergy production are its lower water consumption for growth than other crops and the fact that it can be cultivated in non-arable lands, without competing with food crops [6-8].

Over the past thirty years in Scotland, the grass over five years old increased in more than $48 \%$ due to the abandonment of farmland and grazing produced in turn by the decrease in animal husbandry; the same process is occurring in most developed countries. For that reason, grass should be considered as biomass feedstock for bioenergy production, and in particular for biogas production. At present there is no anaerobic digestion plant in Scotland using grass as feedstock, very different is the situation in Northern Ireland where all the nine existing AD plants use grass for co-digestion alongside with other substrates, usually animal manures. In Germany, already $30-40 \%$ of the biogas plants operate with grass or grass silage as co-substrate, with an average of $8 \%$ by weight of grass silage in the total substrate, reaching in some case $50 \%[9,10]$. A useful tool in cases of biomass utilization plants and biomass to biofuel projects is the quantification of biomass potential;

Christoforou et al. (2015) document the existing plant-derived biomass potential quantification methods and deliver a framework for the definition of biomass resources [11].

In crop production, energy is required for tillage, crop seedlings, fertilising, herbicides application, harvest and transport. Furthermore, considerable energy is required for the production of herbicides, fertilisers and pesticides. On average, fertiliser production represents about $50 \%$ of total energy requirement, the $22 \%$ are required for machinery, about $15 \%$ for transport fuel and $13 \%$ for pesticides [12]. Due to the fact that grass is not cultivated but it grows naturally, the higher energy demanding processes (fertilizer and pesticide production and application) are not necessary, therefore the energy balance is presumed more advantageous although biogas yields are not as high as in other crop species.

\section{Biogas production from grass}

Anaerobic digestion is a microbial fermentation in the absence of oxygen resulting in a mixture of gases (mainly methane and carbon dioxide), known as "biogas" and an aqueous slurry or "mud" containing the microorganisms responsible for the degradation of organic matter [13]. The raw material subjected to this treatment is preferably any residual biomass that has high moisture content, such as food scraps, leftover leaves and herbs from garden or orchard cleaning, livestock waste, 
domestic and industrial wastewater, sludge from water treatment plants and urban waste. The main product of anaerobic digestion, the biogas, is a mixture of methane (50-70\%) and carbon dioxide (30$50 \%$ ), with small proportions of other components (nitrogen, oxygen, hydrogen, hydrogen sulphide), whose composition depends on the raw material and the process parameters such as HRT or temperature $[5,14-16]$. Considering methane has a higher heating value (HHV) of ca. $37.8 \mathrm{MJ} / \mathrm{m}^{3}$ and carbon dioxide has no energy associated with it, biogas has an energy content of between 19 and $26 \mathrm{MJ} / \mathrm{m}^{3}$ and it can replace natural gas in combined heat and power plants (CHPP) undergoing previously a purification process to reduce the $\mathrm{CO}_{2}$ content and eliminate contaminants as sulphides [17-20]. At the end of the anaerobic digestion, the nutrients remain largely contained in the digestate, thus, a nutrient-rich digester residue remains and it can be used as fertilizer. Legal requirements such as laws governing fertilizer, hygiene and solid waste must always be observed in the further use of the digestate as fertilizer.

The grass composition, the harvesting time, the chopping size and the use of ensiling agents are important factors that influence the feedstock quality [10]. The results of fermentation tests indicate that the optimal cutting time of grass for anaerobic digestion should be around three or four days after that the grass used for dairy cattle feeding [21]. The percentage of cell wall components (cellulose, hemicellulose and lignin) increases with increasing maturity of the grass, whereas the percentage of cell contents (protein, lipid, sugars) decreases (Figure 1) [22]. To achieve high methane yields, crop substrates need a low lignin content as well as a high content of easily degradable components such as carbohydrates and soluble cell components $[23,24]$. Two key parameters in the biogas production from grassland: sugar and fibre content, can be optimized by selecting the suitable harvesting time [10]. Grass can be harvested once or twice per year with conventional haying equipment. Harvesting once a year has the economic advantage of being cheaper than cutting twice and fewer nutrients will be removed from the soil. In autumn the harvesting time is preferable at least one month after the first heavy frost as nitrogen and some potassium will move into the root system and the cutting height should be 6 to 8 inches. The cutting height when harvested during spring should be 8 to 10 inches, at this stage, sufficient carbohydrate reserves have been built up and allow for rapid regrowth $[6,25,26]$. Switchgrass harvested in spring has lower mineral (potassium and chlorine) concentrations than switchgrass harvested in autumn. Meadow foxtail grassland harvested monthly from June to March in northeast Germany resulted in specific biogas yields decreasing throughout the season from 547 $\mathrm{l} / \mathrm{kgVS}$ in June to $299 \mathrm{l} / \mathrm{kgVS}$ in February, the methane yields showed a parallel pattern from 298 $\mathrm{l} / \mathrm{kgVS}$ in June to $155 \mathrm{l} / \mathrm{kgVS}$ in February whereas the methane percentage stays constant in a mean value of 52 over the year [27]. 
Growth rates of plants are regulated by the photosynthetic ability and a multitude of environmental factors. Grasses are classified into C3 and C4 species based on their photosynthetic pathway. Anatomical differences in leaf and bundle sheath cells occur between C3 and C4 grasses $[28,29]$. Typically, the optimum light intensity for $\mathrm{C} 4$ species is twice that for $\mathrm{C} 3$ species, for that reason $\mathrm{C} 4$ grasses are common in tropical regions while C3 grasses are more abundant in European countries. Grasses are classified into annual species, which include many cereals, and perennial species, which include many forage grasses. Tropical grasses grow faster than trees and produce higher biomass in a shorter period. [30].
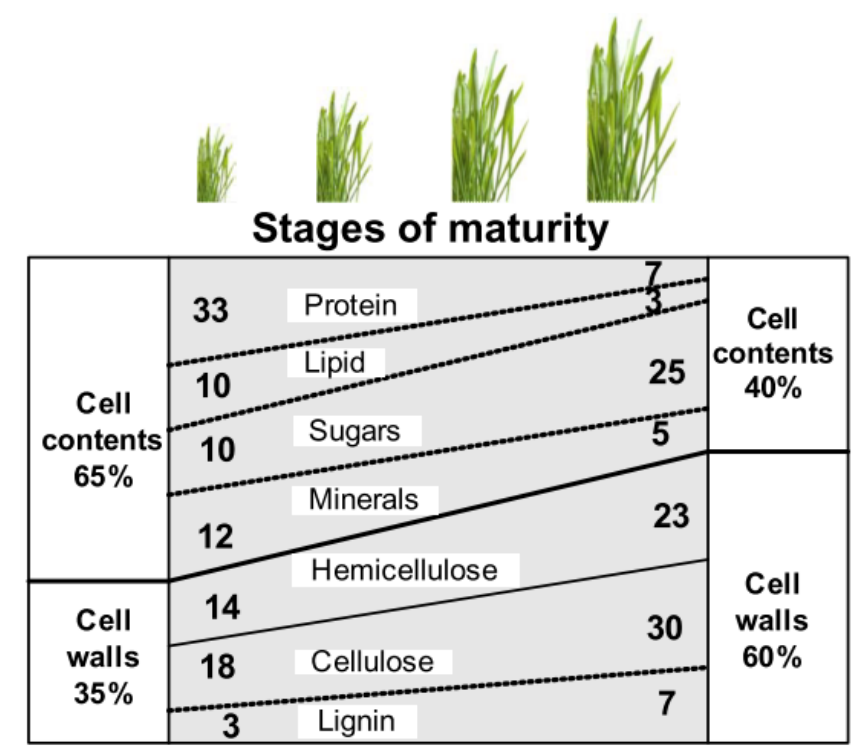

Figure 1. Values of grass components through maturity stages [31].

The type of grass used is another factor that affects the biogas production, depending on the grass specie, its composition vary, therefore the substrates available for anaerobic digestion are different for each grass type. Figure 2 shows the most common grass varieties for anaerobic digestion. The most important grass specie in Europe is perennial ryegrass; other important grass species are meadow fescue, Italian ryegrass, tall fescue, timothy and cocksfoot [3].

Biogas yield from a cultivated variety of canary grass was $406 \mathrm{Ndm}^{3} / \mathrm{kgVS}$ meanwhile for a wild grass was $120 \mathrm{Ndm}^{3} / \mathrm{kgVS}$ [32]. Similar results were obtained when compared lawn cuttings and wild grass, where wild grass showed a lower biodegradability and lower biomechanical methane potential (BMP) than lawn cuttings, owing to its low lignin and lignocellulose content and low crystallinity of cellulose [33]. Fresh grass most of the times results in bigger biogas production that ensiled grass. Mähnert et al. (2005) compared the methane and biogas production of seven types of fresh and ensiled grass, the results for biogas yield were: perennial ryegrass 904/929 l/kgoDm (fresh/ensiled), cocksfoot 
800/718 l/kgodm, tall fescue 836/818 I/kgodm, red fescue 845/767 I/kgodm, meadow fescue 909/846

I/kgodm, meadow foxtail 804/n.r. I/kgodm and timothy 828/591 I/kgodm [1,34,35].

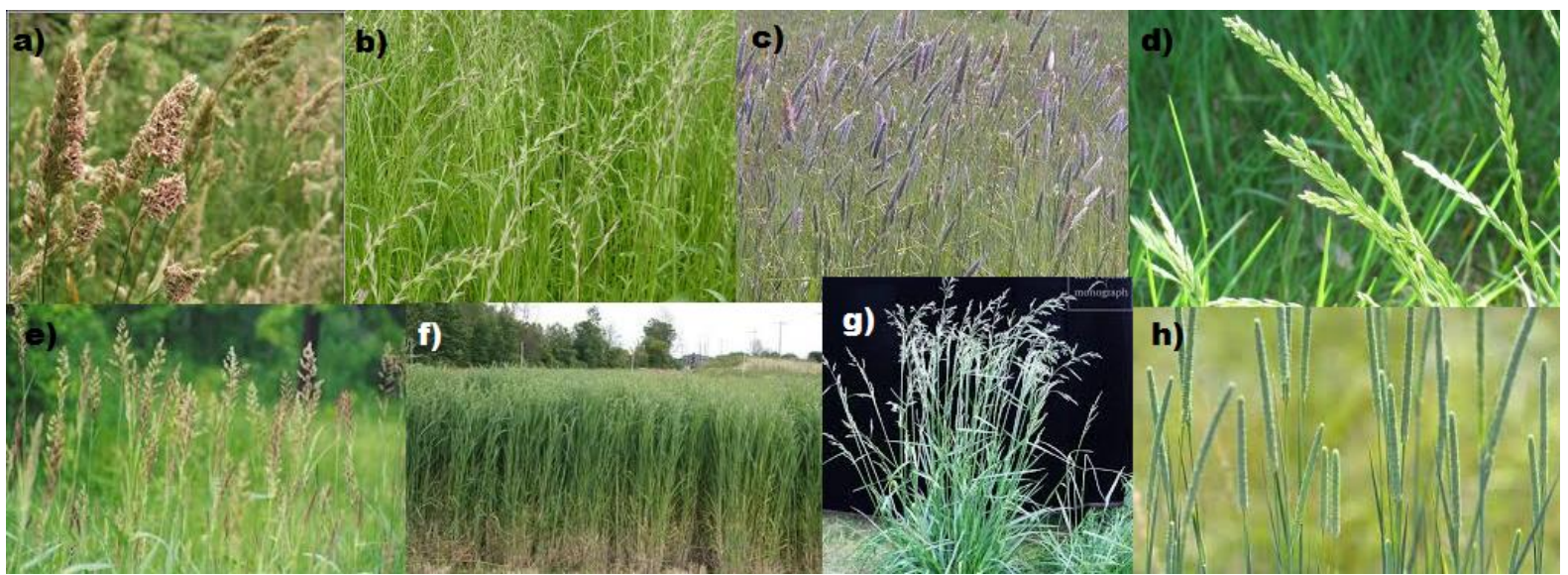

Figure 2. Varieties of grass: a) Cocksfoot, b) Italian ryegrass, c) Meadow foxtail, d) Perennial ryegrass, e) Reed canary, f) Switchgrass, g) Tall fescue and h) Timothy-grass

\section{Pretreatment of grass}

Lignocellulosic biomass has a complex internal structure. It contains a number of main components (cellulose, hemicellulose and lignin) that have, in their turn, also complex structures (Figure 3) [36]. Before undergo anaerobic digestion the grass should be suitably conditioned in order to offer the microorganisms in the digester a larger target surface area and thus to improve and accelerate the degradation process [37-39]. 


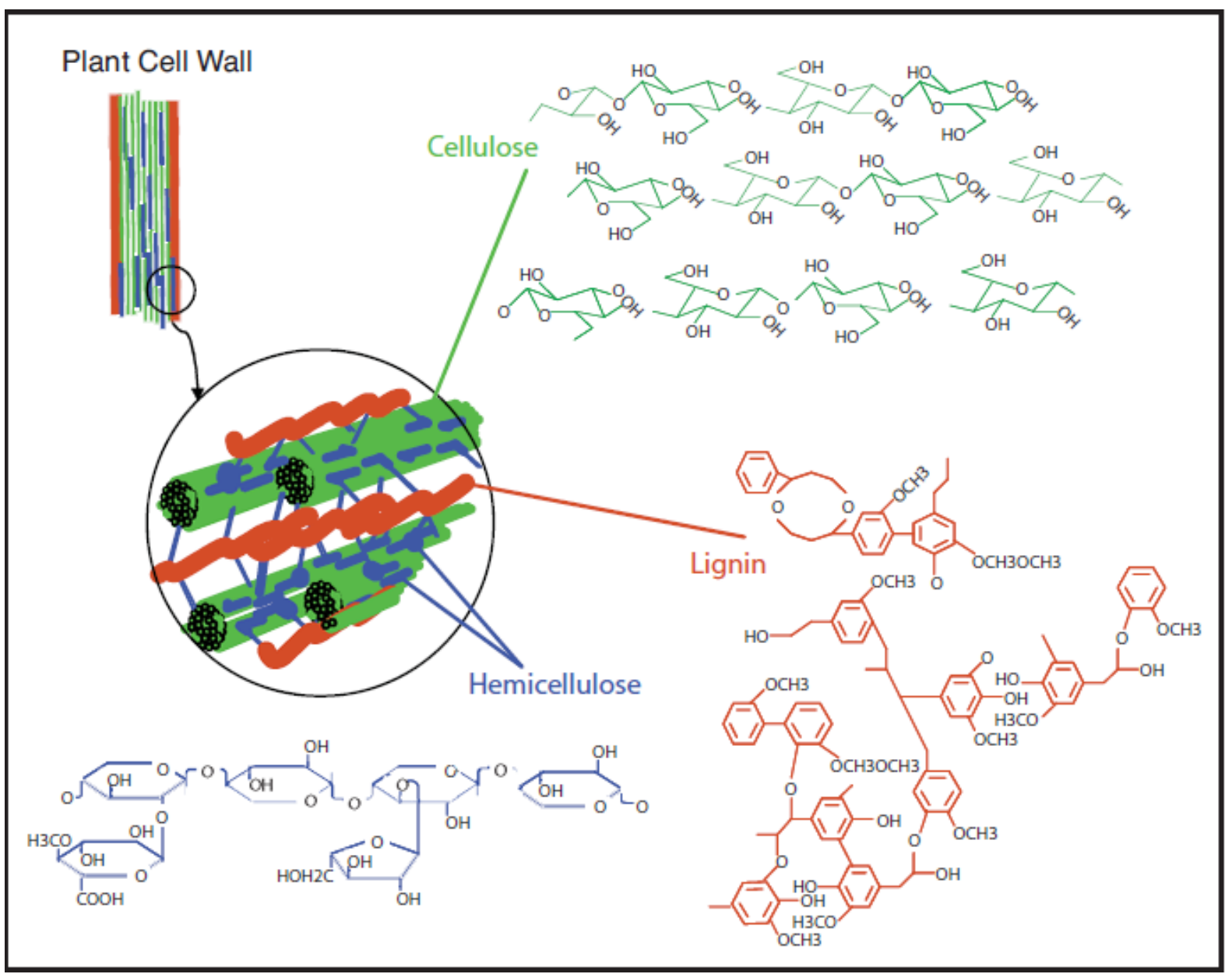

Figure 3. Lignocellulosic biomass internal structure [40].

\subsection{Physical}

Physical pretreatment refers to those methods that do not use external compounds such as chemicals, water or microorganisms during the pretreatment process. In this paper physical pretreatment methods studied are classified as: mechanical, ultrasound and microwave methods.

\subsubsection{Mechanical}

Chipping is a mechanical pretreatment that is widely used for big waste materials such as agricultural residues from straw, corn stover or any other crops and forestry residues as wood chips [41]. The objective of chipping is to reduce heat and mass transfer limitations caused by large size particles [42]. After chipping the final particle size of materials is usually $10-30 \mathrm{~mm}$ [43]. Disk chippers are the most popular type of chippers, in disk chippers straight knives are attached to a revolving heavy disk. The disk rotates at speeds that vary between 400-1000 rpm [44]. Owing to the limitation of particle size reduction, this technique is less effective than milling and grinding in which it is possible to reduce the particle size up to $0.2 \mathrm{~mm}$. For this reason, no chipping techniques were applied to grass 
for anaerobic digestion up to date. However, it was reported that reducing the particle size of feedstock beyond $0.4 \mathrm{~mm}$ does not improve the biogas yield $[42,45-48]$.

Grinding and milling are methods to treat compact and difficult-to-handle biomass such as hard food wastes, waste paper or wood [49-52]. The grinding method depends on the dimensions, mechanical properties, and moisture content of the biomass. Screw shredders, scissors, knife, and hammers are the most common appliances for grinding. Grinding pretreatment was applied to different feedstock such as alfalfa chops, corn residues and grain sorghum [53-55]. The hydrolysis yield of wheat straw subjected to a grinding process increased from $6 \%$ to $34 \%$, the reduction of particle size favoured the contact between the enzymes with the substrate and revealed new zones which contained initially inaccessible polymers in coarse particles. Wheat straw particles were ground until passing through a sieve, the particle size reduction is caused by high-speed mechanical impacts and cutting the feedstock by knifes mounted in the rotor [56].

Knife milling technique is usually used for wet feedstock where it is being continuously cut until it is small enough to pass through a sizing screen. The cutting process occurs by rotary equipment consisting of 4-6 knives mounted on a solid steel rotor spinning at between 500 and 600 RPM. Ball mills comprises a drum, where all contained materials are meant for crushing and grinding, such as balls of ceramic, small rocks, or balls made from stainless steel. This method reduce the polymerization degree and crystallinity of cellulose and the feedstock particle size and increases the bulk density allowing the treatment of more concentrated feedstock and reducing the reactor volume [43]. Another milling technique, "Hammer mill", is based in a rotor with attached hammers that push the material against a breaker plate, the hammers impact the feedstock and it is thereby shredded and expelled through screens. Bitra et al. [57] successfully used a hammer mill to treat different types of biomass such as corn stover and wheat straw. In disc mills, biomass is fed through an orifice coaxially with the rotation axis; a moving grinding disc rotates against a fixed one and draws in the feed material. This type of mill can be built in a single or double disc version. The comminution is generated by pressure and frictional forces: the grinding disc meshing first subjects the sample to preliminary crushing due to the centrifugal force, and then moves it to the outer regions of the grinding discs where fine comminution takes place. The processed feedstock exits through a grinding gap, which can be adjusted for its collection. Disc mills use more energy that hammer mills but produced particles with smaller-size distribution $[51,58]$.

Lindmark et al. (2012) pretreat ley crop silage with two machines originally used in the paper and pulp industry, the Krima disperser and the Grubben deflaker $[59,60]$. The deflaker system consists of two discs with teeth, one disc rotates and the other is stationary; the feedstock is pumped into the 
stationary disc passing the teeth which rip up the fibre structure and the fibre pulp is hurled to the outlet. As well as for the deflaker, the disperser is based in rotor discs, which grind the material as it passes through the narrow openings between the discs. During the treatment, the biomass passes through a screw and in a following step, the material is mixed with water before reaching the grinding sections. The operation of both systems is shown in Figure 4. The pretreatment with the Grubben deflaker increased the methane production of ley crop silage by $59 \%$ and with the Krima disperser by $43 \%$, compared to untreated material, this means an increase in the energy output per hectare of farmland by 3-4MWh [61]. The Krima disperser resulted in a larger size distribution, resulting in particles of more than $8 \mathrm{~mm}$ in size while the Grubben deflaker reduced about $90 \%$ of the material to less than $2 \mathrm{~mm}$ in size.
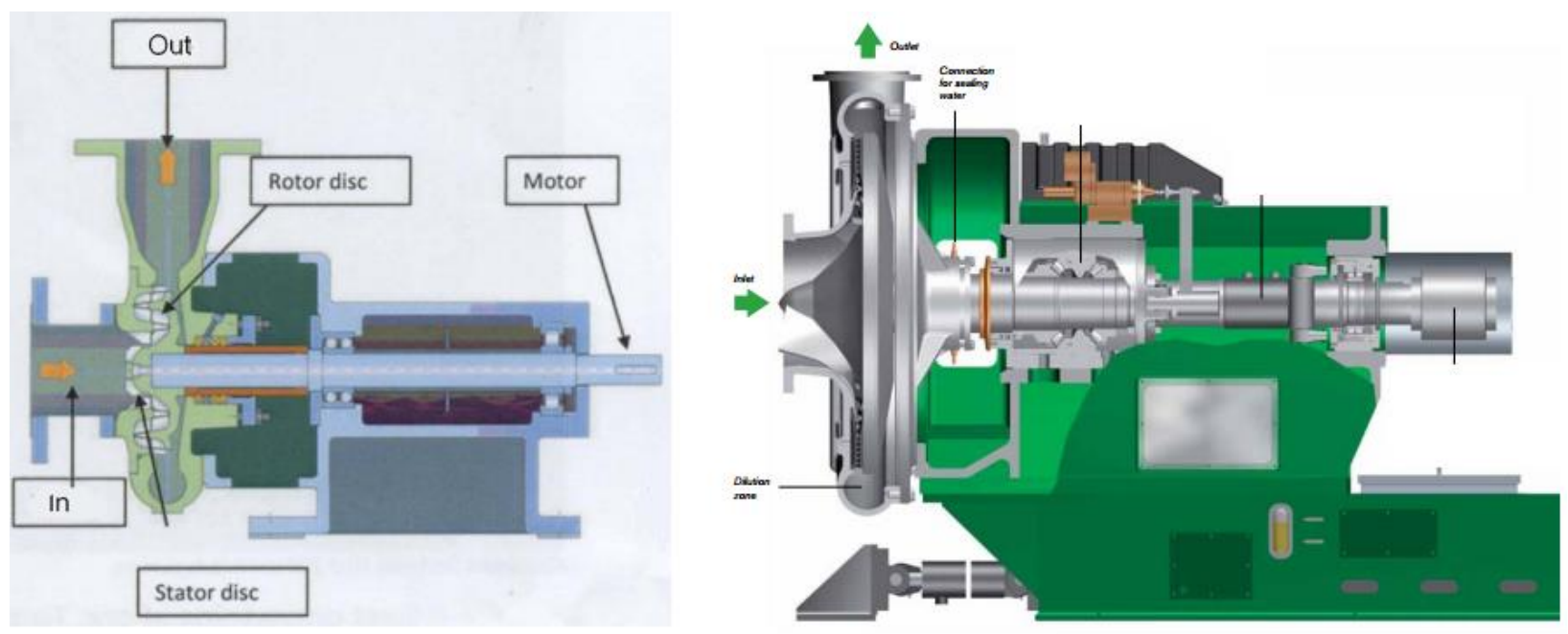

Figure 4. Grubben deflaker (left) and Krima disperser (right).

The effect of the particle size was investigated in six hay samples collected from local farms in Estonia, the hay was comminuted with a knife mill and laboratory scissors before the anaerobic digestion. Final particle sizes of $0.5,4$ and $10 \mathrm{~mm}$ were achieved with the knife mill, while with the laboratory scissors the hay was cut into $2-3 \mathrm{~cm}$ pieces. The results show that there is a negative correlation between biogas yield and particle size as well as for lignin content [62].

Tsapekos et al. studied six mechanical pretreatment methods to treat ensiled meadow grass; the pretreatments are based in the combination of two out of four commercially available heavy plates, each with a different shaped pattern. Ensiled meadow grass was placed between the plates; the upper plate was manually pushed back and forth, using two hand grips, across the bottom plate for four times without applying any downward force on it; the friction cut the grass reducing its length, the operation principle is shown in Figure 5. The higher biogas production was achieved with the sample with more percentage of small particles $(22 \%$ of $0-5 \mathrm{~cm}$ particles), enhancing the methane production 
by approximately $25 \%$. The least efficient pretreatment method resulted only in $8 \%$ biogas enhancement, which corresponds to the sample with a $45 \%$ of particles longer than $15 \mathrm{~cm}$ [63].

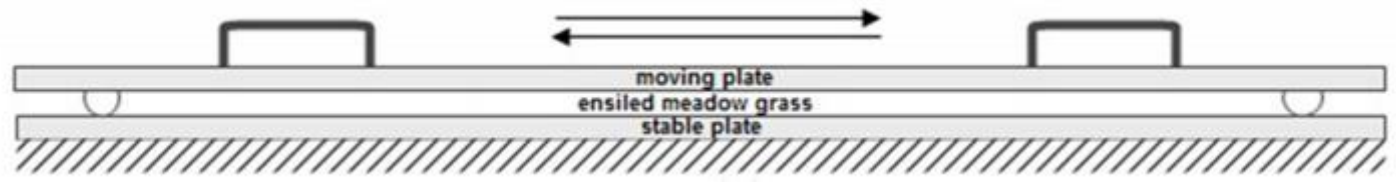

Figure 5. General principle of mechanical pretreatment in Tsapekos et al. study [63].

Extrusion is another mechanical process adapted from other industries such as metal and plastic forming. The feedstock is subjected to heating, mixing and shearing, causing the break of fibres and the plant cells lysing, as the feedstock leaves the extruder, the sudden drop in pressure causes evaporation of intracellular water that helps the substrate breakdown. The applied shear forces serve to continuously remove the softened surface regions of the substrate and expose the interior to the biological action, thus improving the overall rate of decrystallization [64]. Twin-screw extruders, where the screws rotate counter wise, are typically used; the major drawback is that the screws have to be changed regularly due to abrasion. Feedstock with solid content of 30 to $35 \%$ cannot be extruded at temperatures over $100^{\circ} \mathrm{C}$ due to water evaporation and substrate drying [65]. Extrusion was applied as pretreatment for different biomass feedstock as barley straw, grass, pig and cow manure. A methane yield increase of $11.5-13.4 \%$ was achieved when maize was previously extruded [66].

Extruded grass produced $62 \%$ higher methane yield after 28 days of digestion time and by $9 \%$ after 90 days compared to untreated feedstock. The electrical yield (determined by comparing the electrical energy produced by un-extruded material and the electrical energy produced by extruded material after subtracting the electrical energy input for the extruder) also increases after 28 and 90 days of anaerobic digestion by 47 and $7 \%$ respectively [67]. By means of an adjustable opening present at the outlet of the extruder it was possible to modify the extrusion intensity level. The methane yield was proportional to the extrusion intensity for ryegrass, where the pretreatment achieved an increase of 7.1-8.5\% for two different levels of extrusion. The energy efficiency, calculated as ratio of energy output to energy input, is also higher for the higher level of extrusion intensity with a value of 2.9 [66]. Extruded meadow grass (Figure 6 ) increase the biogas production by $27 \%$ compared to non pretreat material [68]. 


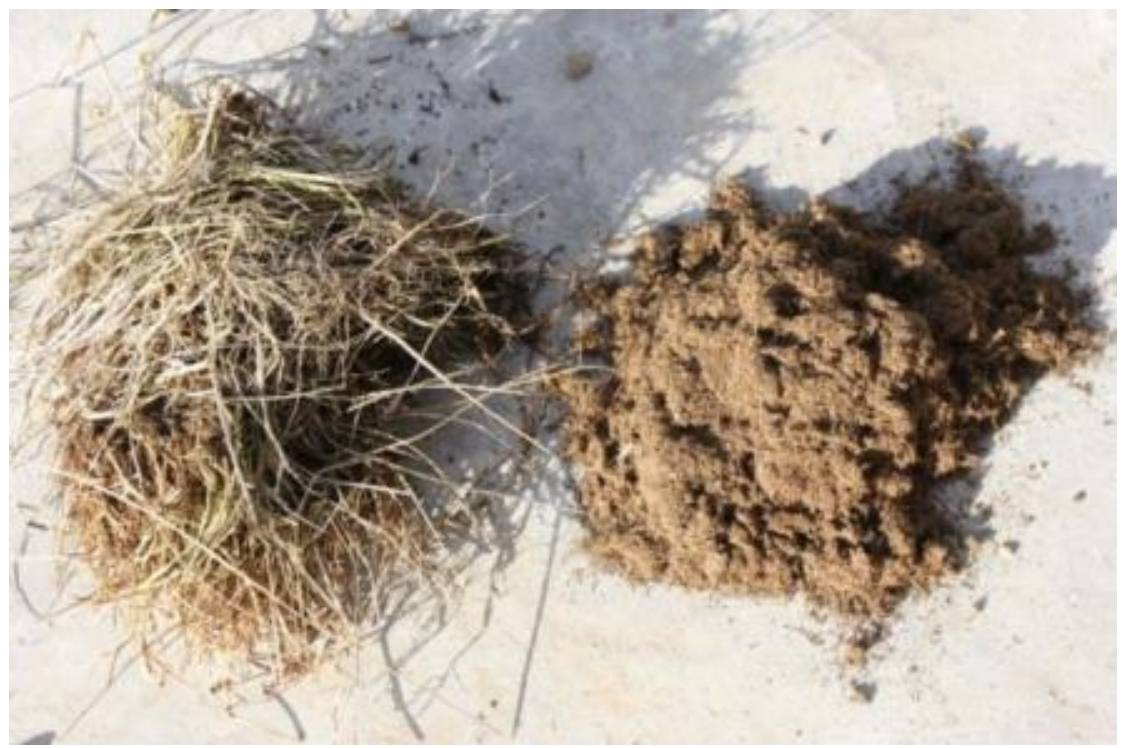

Figure 6. Meadow grass before (left) and after (right) extrusion treatment [68].

\subsubsection{Ultrasound}

Acoustic energy in the form of waves with a frequency above the human hearing range is called ultrasound. This high frequency of sonic waves causes cavitation inside the cells and regions with liquid vapour, so-called microbubbles are formed. Cavitation provides the physical effects of microturbulence and velocity/pressure shockwaves. Frequencies on the order of $\mathrm{KHz}$ and high amplitudes induce cell lysis releasing the intracellular material, cavitation promotes chemical reactions to destroy organic matter due to the high local temperatures and pressures, creating extreme shear forces in the liquid and leading the formation of reactive radicals $(\mathrm{H}+$ and $\mathrm{OH}-)$, furthermore, the hydrolysis of the biomass is accelerated and subsequently VFAs are more readily generated and transformed into methane. Schwede et al. found that micro-algae Nannochloropis salina samples with higher VS degradations resulted in lower specific biogas productions contrary to expectations, author mention this is a sign for possible loss of volatile organic material during cell disruption by ultrasounds [69-73]. Samson and LeDuy (1983) explained this effect by changes in the chemical composition of the culture media due to cell disruption [74], while Gonzalez-Fernandez et al. (2012) state that at different sonication energies, different types of organic matter were released. At low energies, no cell lysis occurs and COD solubilisation is due to exopolymer dissolution which did not increase methane production. In contrast, at higher energies the disruption of the cell contributed to enhanced methane production [75]. Ultrasound pretreatment has been used for many different types of biomass including cattle and chicken manure, olive mill wastewater and sludge [76-79] however up to date it has not been proved on grass. All the previously mentioned types of biomass has a high percentage of water in their composition and ultrasound pretreatment have been found be more effective when lignocellulosic materials are mixed with water [80]. This is due to the better sound transmission in the 
interface water-solid than in the air-solid one, therefore if ultrasound pretreatment will be applied to grass for biogas production, it is highly recommended to mixture the biomass with water before pretreatment.

\subsubsection{Microwave}

Microwaves are short waves of electromagnetic energy varying in a frequency from 0.3 to $300 \mathrm{GHz}$, industrial and domestic microwaves ovens operate at $2.45 \mathrm{GHz}$. These waves increase the kinetic energy of the water leading to a boiling state; the process polarizes macromolecules, causing changes in the structure of proteins and a rapid generation of heat and pressure in the biological system that produce cell hydrolysis, forcing out compounds from the biological matrix. A uniform microwave irradiation generates energy through the realignment of dipoles with oscillating electric fields to generate heat both internally and at the surface of the treated material, heating more quickly all parts than conduction methods. Also, microwave heating units feature instant on/off, so no equipment warm-up or cool down is necessary. Under microwave irradiation, lipids are hydrolysed to palmitic acid, stearic acid, and oleic acid; proteins are hydrolysed into saturated and unsaturated acids, ammonia, and carbon dioxide; and carbohydrates are hydrolysed into lower molecular weight polysaccharides [81-84]. Microwave pretreatment is used in different types of biomass in order to improve the biogas yield [85-88].

Microwave pretreated Pennisetum hybrid resulted in a specific methane yield decrease from 189.7 $\mathrm{mL} / \mathrm{gVS}$ correspondent to raw material to $163.6 \mathrm{~mL} / \mathrm{gVS}$ after $3 \mathrm{~min}$ pretreatment [89]. Similar results were obtained with switchgrass, microwave pretreatment has no significant effect on the ultimate volume of methane produced, however, kinetics of methane production was increased; the time needed to reach the $80 \%$ value of ultimate volume of $\mathrm{CH}_{4}$ was reduced by 4.5 days [90]. (Table 1) summarizes the mechanical and microwave techniques above explained.

Table 1. Physical pretreatments for grass biogas production.

\begin{tabular}{lllll}
\hline Pretreatment & Machine & Feedstock & Results & References \\
\hline Mechanical & Grubben deflaker & Ley silage & $+59 \% \mathrm{CH}_{4}$ production & {$[61]$} \\
& Krima disperser & Ley silage & $+43 \% \mathrm{CH}_{4}$ production & {$[61]$} \\
& $\begin{array}{l}\text { Knife mill and laboratory } \\
\text { scissors }\end{array}$ & Hay & Negative correlation & [62] \\
& Heavy plates & Meadow grass & $+25 \% \mathrm{CH}_{4}$ production & {$[63]$}
\end{tabular}




\begin{tabular}{|c|c|c|c|c|}
\hline \multicolumn{2}{|c|}{ Extruder } & Festulolium & $+62 \% \mathrm{CH}_{4}$ yield & [67] \\
\hline & Extruder & Reygrass & $+8.5 \% \mathrm{CH}_{4}$ yield & [66] \\
\hline & Extruder & Meadow grass & $+27 \%$ biogas production & [68] \\
\hline \multirow[t]{2}{*}{ Microwave } & $400-1600 \mathrm{~W}$ & Switchgrass & Increase in $\mathrm{CH}_{4}$ kinetics & [90] \\
\hline & $1180 \mathrm{~W}$ & Pennisetum hybrid & $-13 \% \mathrm{CH}_{4}$ yield & [89] \\
\hline
\end{tabular}

\subsection{Thermal}

Thermal pretreatment is effective in the degradation of lignin and hemicellulose, heat break up the hydrogen bonds in crystalline complexes of cellulose and lignocellulose, causing the biomass to swell, thus increasing the accessible surface area. Thermal pretreatment is carried out in most cases in autoclaves, pressure cookers or jacketed reactors (laboratory scale); dry substrates need the addition of water before the treatment. It was shown that thermal pretreatment reduces the viscosity of sewage sludge when it is used as feedstock for anaerobic digestion [91], as viscosity is an important operational parameter in biological processes, reducing the biomass' viscosity facilitates the reactor feeding. Inhibitory or toxic effects may be caused to bacteria, yeast and methanogens due to the phenolic compounds produced from the solubilisation of hemicellulose and lignin. Thermal pretreatment can be carried out alongside chemical addition; usually, the addition of an acid or an alkali improves the pretreatment' effectiveness. The sanitisation of the feedstock is a further advantage of thermal pretreatment, applying high temperatures, the pathogens are eliminated. This effect is particularly advantageous when the biomass is stored and not used right following the pretreatment $[89,92-94]$. The effect of thermal pretreatment was extensively investigated in different biomass including sugarcane, algae, sugar beet pulp and sunflower oil cake [13,95-98].

Thermally pretreated Pennisetum hybrid resulted in a specific methane yield increase from 189.7 $\mathrm{mL} / \mathrm{gVS}$ correspondent to raw material to $198.3 \mathrm{~mL} / \mathrm{gVS}$ after $30 \mathrm{~min}$ water vapour pretreatment [89].

Dry hay was pretreated by steam explosion at temperatures ranging from 160 to $220^{\circ} \mathrm{C}$. Steam explosion pretreatment is based on steam injection to the sample followed by an abruptly pressure reduction, which make the biomass suffer an explosive decompression producing the hydrolysis of the hemicellulose into individual sugars. The maximum methane yield increment of $16 \%(281 \mathrm{IN} / \mathrm{kgVS})$ was resulted when the biomass was pretreated at $175^{\circ} \mathrm{C}$ for $10 \mathrm{~min}$. Higher temperatures markedly decreased the methane yield, this can be attributed to the formation of substances inhibiting the 
microorganisms responsible for the anaerobic digestion process (e.g. phenolic compounds or furan derivatives) as well as to the loss of sugars due to pseudo-lignin formation [99].

A hyperthermophilic pretreatment at $80^{\circ} \mathrm{C}$ was applied to a mixture of shredded grass and sewage sludge. Under mesophilic conditions and with a retention time of 3 days, the methane yield increased from 212.6 Nml/g VS (raw mixture) to $309.7 \mathrm{Nml} / \mathrm{g}$ (pretreated mixture). Under thermophilic conditions and 4 days of retention time, the methane yields were $279.5 \mathrm{Nml} / \mathrm{g}$ VS for raw material and 339.9 $\mathrm{Nml} / \mathrm{g}$ VS for the pretreated mixture. The CODs increased significantly from $9.1 \mathrm{~g} / \mathrm{L}$ correspondent to raw mixture to $19.4 \mathrm{~g} / \mathrm{L}$ after pretreatment [100].

\subsection{Chemical}

Although cellulose has a crystalline structure and great resistance to acids and alkalis [101], these compounds are commonly used to solubilize the hemicellulose and lignin presented in the biomass, making them more available for enzymatic attacks. Acid pretreatment is indicated for hemicellulose solubilisation, whereas alkaline pretreatment was found more effective in lignin removal [93,102-104]. The most commonly alkalis used (sodium, ammonium, calcium and potassium hydroxides) have been used for the pretreatment of lignocellulosic materials, the alkali pre-treatment's effectiveness depends on the lignin content of the biomass. This pretreatment produces the saponification and cleavage of lignin-carbohydrate linkages, increases the porosity and internal surface area of biomass, and decreases the degree of polymerization and crystallinity of feedstock. Chemical pretreatment technology is generally considered unattractive economically, but may be used in lignin rich biomass that otherwise could not be digested. The residual alkali remaining in alkali-pretreated biomass could help to prevent a drop in $\mathrm{pH}$ during the acidogenesis step. Acid pretreatment can be conducted either by a concentrated acid or by a dilute acid, sulphuric acid is the most commonly used, hydrochloric acid, nitric acid, and acetic acid, have also been used. Concentrated acid is highly effective on cellulose hydrolysis; however it is an energy and cost intensive process. Concentrated acid is greatly toxic and corrosive, therefore special materials are required for the reactors construction. Dilute acid is a more economic choice and for lignocellulosic biomass pretreatment can hydrolyses up to $100 \%$ of the hemicellulose into its component sugars $[48,94,105,106]$.

Calcium hydroxide $\left(\mathrm{Ca}(\mathrm{OH})_{2}\right)$ pretreatment was applied to grass biomass at different loading rates; results showed that higher lime concentration results in better methane production. At $52^{\circ} \mathrm{C}$, when the lime concentration is $0.8 \%$, the methane production increased by $4 \%$; and for a lime concentration of $9.2 \%$, the methane production increased by $14 \%$. However, the best result was achieved at $10^{\circ} \mathrm{C}$ and $7.5 \%$ loading rate, with an increase in methane production by $37 \%$ [107]. 
The Fenton oxidation process, in which $\mathrm{Fe}_{2}+$ reacts with $\mathrm{H}_{2} \mathrm{O}_{2}$ to generate $\cdot \mathrm{OH}$, was employed to degrade organic compounds. The mixture of $\mathrm{FeSO}_{4}$ and $\mathrm{H}_{2} \mathrm{O}_{2}$ (Fenton's reagent) at low pH decomposes organic compounds in a short time [108]. Pretreating three types of grass with Fenton's reagent, the biogas productions were $25.2 \mathrm{Ndm} 3 / \mathrm{kgTS}$ for Sorghum, $26.1 \mathrm{Ndm} 3 / \mathrm{kgTS}$ for Sida and 13.6 Ndm3/kgTS for Miscanthus [109].

\subsection{Biological}

Biological pretreatment of biomass is based in three main actions, bacterial, fungi and enzymatic activity. Brown-, white- and soft-rot fungi are used to degrade lignocellulosic biomass. White and soft rots fungi attack cellulose and lignin, while brown rots attack mainly cellulose. White-rot was proved as the most effective among fungi for lignocellulosic biomass degradation. Pre-acidification, also known as anaerobic microbial pretreatment, can be used as pretreatment method for improving biogas production: in this process the first steps of the anaerobic digestion, hydrolysis and acidogenesis, occur separated from the final methane production step. Through the separation of the phases, it is possible to avoid the inhibitory effects on methanogens produced by the accumulation of volatile fatty acids. Enzymatic hydrolysis is another type of biological pretreatment. Although enzymes are already present in the digesters as they are produced by the digestion microorganisms, an enzyme or mixture of enzymes can be added in order to enhance the biomass degradation. Cellulose, hemicellulose-, and starch-degrading enzymes are the more frequently used for lignocellulosic feedstock. Enzymatic hydrolysis pretreatment can be an alternative to energy-demanding thermal and mechanical pretreatments and also to chemical pretreatments as enzymes are much more safety compounds than chemicals. However, biological processes are high time and space demanding, usually it is necessary 10-14 days of residence time, then, at higher residence time, higher reactor volume is required. Biological pretreatment can be used on its own or combined with other pretreatment methods if there is a high concentration of recalcitrant compounds $[42,93,94,110]$.

Napier grass was pretreated with three microbial consortia MC1, WSD-5 and XDC-2 for different times, $3,7,13,17$, and 21 days. MC1 comprises thermophilic bacteria, mainly cellulose-degrading bacteria Clostridium straminisolvens. WSD-5 comprises fungal and bacterial communities, the most dominant fungi is Coprinus cinereus and bacteria is Ochrobactrum sp. XDC-2 was mainly composed of mesophilic bacteria in the genera Clostridium, Bacteroides, Alcaligenes, and Pseudomonas. The yields for treated grass were higher than for the untreated samples except the 21 days pretreatment with MC1 and XDC-2 consortia. The maximum methane yields for MC1, WSD-5 and XDC-2 pretreated samples were 1.39, 1.49 and 1.32 times greater than for untreated samples [111]. 
Ligninolytic fungus Phanerochaete flavido-alba was used to pretreat grass of verge before undergoes anaerobic digestion. Despite the pretreatment led to a decrease in all lignocellulose fractions (Cellulose, hemicellulose and lignin), biogas production was similar in non-inoculated substrates than in inoculated, but no explanation was given about this result by the authors. The same pretreatment is effective for wood fiber [112].

In 1963 Dewar et al. showed that during ensiling considerable amounts of sugars were produced from hemicelluloses by acid hydrolysis over a 90-day period. These changes in biomass composition suggest that ensiling may be considered as a biological pretreatment method for cellulosic biogas production [113]. The ensiling process involves the production of organic acids and a decrease in $\mathrm{pH}$ that consequently prevents growth of fungi, yeasts and bacteria which may otherwise decompose the carbohydrate structure of biomass [114]. Biomass composition, biomass dry matter at ensiling, and microbial community are the main factors influencing ensiling. Combination of storage and pretreatment at ambient temperature and pressure as in ensiling holds a considerable potential cost and energy savings $[113,115]$.

Ensiling assisted with two inocula, LACTISIL Grass plus (GP) and LACTISIL CCM (CCM) was applied as pretreatment for Festulolium Hykor grass. GP inocula consist of the lactic acid bacteria (LAB) Pediococcus pentosaceus and Lactobacillus plantarum, which are both homofermentative. CCM inocula consist of pure Lactobacillus buchneri which is heterofermentative. Ensiling had a positive effect on the sugar release by generally yielding higher amounts of sugar per biomass gram; however, the inocula did not affect the acid production of the ensiling. This no effect can be explained by the fact that the natural epiphytic organisms on the grass dominated the fermentation processes rather than the ones presents in the inocula. The maximum cellulose convertibility (CC) after ensiling was $70 \%$, which means an increase of $40 \%$ relative to the dry grass. Table 2 summarizes the thermal, chemical and biological pretreatments applied to grass.

Table 2. Thermal, chemical and biological pretreatments for grass biogas production.

\begin{tabular}{llllr}
\hline Pretreatment & Conditions & Feedstock & Results & References \\
\hline Thermal & Autoclave & Pennisetum hybrid & $+4 \% \mathrm{CH}_{4}$ yield & {$[89]$} \\
& Steam explosion $160-220^{\circ} \mathrm{C}$ & Hay & $+16 \% \mathrm{CH}_{4}$ yield & [99] \\
& Oil bath $80^{\circ} \mathrm{C}$ & Eleusine indica & $+46 \% \mathrm{CH}_{4}$ yield & {$[100]$} \\
\hline Chemical & $\mathrm{Ca}(\mathrm{OH})_{2}$ & Grass & $+37 \% \mathrm{CH}_{4}$ production & {$[107]$}
\end{tabular}




\begin{tabular}{|c|c|c|c|c|}
\hline & Fenton's reagent & Miscanthus giganteus & 13.6 Ndm3/kgTS (biogas) & [109] \\
\hline & Fenton's reagent & Sorghum Moensch & 25.2 Ndm3/kgTS (biogas) & [109] \\
\hline & Fenton's reagent & Sida hermaphrodita & 26.1 Ndm3/kgTS (biogas) & [109] \\
\hline Biological & Microbial Consortium: MC1 & Napier grass & $+39 \% \mathrm{CH}_{4}$ yield & [111] \\
\hline & Microbial Consortium: WSD-5 & Napier grass & $+49 \% \mathrm{CH}_{4}$ yield & [111] \\
\hline & Microbial Consortium: XDC-2 & Napier grass & $+32 \% \mathrm{CH}_{4}$ yield & [111] \\
\hline & Ensiling & Festulolium Hykor & $+40 \% \mathrm{CC}$ & [116] \\
\hline & Fungus: P. flavido-alb & Grass of verge & No effect & [112] \\
\hline
\end{tabular}

\section{Case studies}

Although the information available about the commissioned biogas plants are very scarce as the plants are runner by private companies or small farms who not offer much information, in this section are presented some examples of biogas plant working with grass as feedstock from United Kingdom and Germany.

- Tuquoy Farm

Settle in Westray, Orkney Islands in a family farm of cattle and sheep. The plant has three digesters of 175,75 and $2 \mathrm{~m}^{3}$ respectively which operate at mesophilic conditions. The $2 \mathrm{~m}^{3}$ digester is only used for batch processing trial feedstocks. The digesters are fed with approximately 2,190 T/yr of slurry and $200 \mathrm{~T} / \mathrm{yr}$ of grass silage. In this case the grass represents only the $10 \%$ of the feedstock. No grass pretreatment is made. The gas is use in two 9kW CHP and a gas boiler and the $2200 \mathrm{~T} / \mathrm{yr}$ of digestate produced annually is used on-farm. It is spread mainly on grassland and a barley crop, with fertilizer supplementation [117].

\section{- Devon Farm}

The farm is mainly for grass silage production, with beef cattle and free range chickens. The $500 \mathrm{~m}^{3}$ digester is fed mainly grass and some chicken manure. The digester is heated until mesophilic temperatures by a biogas boiler; the digestate is used on the grassland. Gas is scrubbed by injecting a small amount of air, then used in a $45 \mathrm{~kW}$ CHP. No grass pretreatment is made [117].

- Swancote Energy 
Based in Bridgnorth, England; this biogas plant is operated by Swancote Energy Ltd. since 2011. The plant is formed by three digesters of $2.300 \mathrm{~m}^{3}$. The feedstock is mainly farm residues including food waste, potato peel, yoghourt sludge, maize silage and grass silage. The process temperature is $40^{\circ} \mathrm{C}$ and the HRT 50 days. The plant is provided with gas storage of $4.500 \mathrm{~m}^{3}$ that is used in a CHPP, the heat is used for running a pre-pasteurization system for the feedstock. The digestate is spread out on the fields of the plant owner. No grass pretreatment is made. [118].

\section{- Oberlauterbach-Hallertau}

The plant operated by Bioerdgas Hallertau $\mathrm{GmbH}$ in the Bavaria region, Germany, was specifically designed for processing fibres-rich materials (lignocellulosic). The AD system is made of 3 horizontal digesters and 4 round digesters. The feedstock is composed of $65 \%$ hop silage and $35 \%$ maize/grass silage. The feedstock is pretreated by extrusion and magnets to remove metal contaminants that increases gas yield and reduces pollution on digestate. The mesophilic process temperature is approx. $40^{\circ} \mathrm{C}$ and the HRT 110 days. The biogas produced undergoes upgrading process so that biomethane is injected to the national gas grid (95 million kWh/yr) [119]

\section{- Klostermansfeld}

DSM Food Specialties B.V. operates this plant in Klostermansfeld, Germany. The plant is fed with corn silage, grass silage and grain. Hydrolytic enzyme MethaPlus $₫$ L 100 is used as pretreatment. The results show an increase in both the energy production (12\%) and the mixing properties alongside an increased process stability and reduced digestate through better substrate conversion. The plant operates at mesophilic temperature and with a HRT 106 days. The digester has a volume of $1.600 \mathrm{~m}^{3}$, gas storage of $3.600 \mathrm{~m}^{3}$ and has a capacity of $834 \mathrm{~kW}$ through CHP. The digestate is used as fertilizer [120].

Table 3. Biogas plants with grass as feedstock.

\begin{tabular}{|c|c|c|c|c|}
\hline Plant & Feedstock & Pretreatment & Temperature & Energy production \\
\hline Tuquoy Farm & $\begin{array}{c}2,190 \mathrm{~T} / \mathrm{yr} \text { cattle and sheep manure } \\
\text { 200T/yr grass silage }\end{array}$ & No & Mesophilic & $2 \times 9 \mathrm{~kW}$ CHP \\
\hline Devon Farm & Grass and chicken manure & No & Mesophilic & 45 kW CHP \\
\hline Swancote Energy & $\begin{array}{c}\text { Food waste, potato peel, yoghourt } \\
\text { sludge, maize silage and grass silage }\end{array}$ & No & $\begin{array}{l}\text { Mesophilic } \\
40^{\circ} \mathrm{C}\end{array}$ & $2.000 \mathrm{~kW}$ CHP \\
\hline $\begin{array}{l}\text { Oberlauterbach- } \\
\text { Hallertau }\end{array}$ & $\begin{array}{l}65 \% \text { hop silage } \\
35 \% \text { maize/grass }\end{array}$ & Extrusion & $\begin{array}{l}\text { Mesophilic } \\
40^{\circ} \mathrm{C}\end{array}$ & $11.5 \mathrm{MW}$ \\
\hline Klostermansfeld & Corn silage, grass silage and grain & Biological & Mesophilic & 834 kW CHP \\
\hline
\end{tabular}




\section{Discussion}

The literature available about the pretreatment of grass for biogas production to date is very scarce, for that reason comparing methods is not easy, as most of reported studies applied different pretreatment conditions to different grass species. The energy balance of the pre-treatment method has to be positive for the process in order to be profitable. Economic efficiency is the most important factor that decides what pre-treatment technique should be used. Usually, pre-treatment techniques with lower energy input has a lower impact on biogas and methane yield compared to pre-treatment techniques that require higher energy demand.

The main advantages and disadvantages of grass pretreatment methods are summarised in Table 4. Mechanical pre-treatment is used for grass as well as for other biomass feedstock in order to increase the surface area and make the digestion easier. Remarkably high biogas yield were reported using these methods, with biogas productions increases between 25 and $60 \%$. In mechanical pretreatments, existing machinery from other industries can be used with minor changes or adjustments, but such machinery is highly sensitive to inert materials such as stones or metallic materials that could easily damage it. Additionally, mechanical methods are high energy demanding and have high maintenance costs.

In microwave pretreatment, a cell wall lysis is achieved to make the lipids and proteins more available to digestion, this is based on the disruption of hydrogen bonds that produces changes in protein and lipid structures, the quick penetration into biomass is the main advantage of the process as well as the heat produced that by itself help to biomass disintegration, while the main disadvantage is the high energy consumption, depending on biomass concentration, higher energy supplied usually results in higher biomass solubilisation and greater biogas production. On the other hand, microwave pre-treatment seems to be the easiest method, where the samples are subjected to the irradiation and do not need any further treatment. Samples are introduced into the equipment in buckets, so there is no need to clean the facility after each treatment, and the process normally takes no more than 30 min. To date microwave pretreatment resulted in biogas production reduction around $13 \%$.

Thermal pre-treatment is generally considered as an easy and fast method, it usually takes $10-30 \mathrm{~min}$, but there are some studies where the biomass was subjected to a longer period up to 5 days in the case of using the oil bath [99]. Methane yield increase can vary from 4 to $46 \%$ by using such technique. Additionally, thermal pre-treatment have an additional benefit, the sanitisation of the feedstock. The main disadvantage is that it is a high energy demand process. Another problem that may occur in thermal pre-treatment is the formation of recalcitrant compounds that reduce the 
anaerobic degradability. Energy balance in thermal pre-treatment is related to the solid content of biomass, as it can be improved when biomass is previously dewatered.

Biological pre-treatment is a low energy demanding process compared to other pre-treatments and it doesn't form any inhibitory compounds during the process, while the main disadvantage of this type of pretreatment is that it is a slow process. The enzyme cost should be taken into account, as some enzymes have a relatively high price for a limited increase in methane yield. Different microbial consortiums and the ensiling process can achieve increases in methane yield of $30-50 \%$.

The addition of an alkali or an acid to biomass is another process to improve its degradability. In grass pre-treatment, the chemicals used to date are calcium hydroxide and Fenton's reagent. These compounds improve the solubilisation of hemicellulose with a low energy demand, however, chemical pre-treatment have multiple disadvantages: the possibility of chemical contamination and changes of $\mathrm{pH}$ in the digester leading an interruption in the process. Furthermore, the corrosion problems in the reactor, along with the chemical cost make chemical pre-treatment the one of the most complicated methods to pre-treat grass for biogas production. To date chemical pretreatment resulted in biogas production increase around $37 \%$.

Table 4. Advantages and disadvantages of grass pretreatments.

\begin{tabular}{|c|c|c|c|c|}
\hline Pretreatment & Description & Advantages & Disadvantages & $\begin{array}{c}\text { Effect on } \\
\mathrm{Ch}_{4} / \text { biogas }\end{array}$ \\
\hline Mechanical & $\begin{array}{l}\text { Reduction of cellulose } \\
\text { crystallinity and particle } \\
\text { size. }\end{array}$ & $\begin{array}{l}\text { Biomass easier to handle } \\
\text { Existing machinery. } \\
\text { Improves fluidity in digester } \\
\text { Increase surface area }\end{array}$ & $\begin{array}{l}\text { High energy demand } \\
\text { High maintenance cost } \\
\text { Sensitive to inert materials }\end{array}$ & $+25-60 \%$ \\
\hline Microwave & $\begin{array}{l}\text { Disruption of hydrogen } \\
\text { bonds } \\
\text { Changes in protein and } \\
\text { lipid structure }\end{array}$ & Quick and uniform heating & High energy demand & $-13 \%$ \\
\hline Thermal & $\begin{array}{l}\text { Heat application in the } \\
\text { range } \\
\text { of } 50-250^{\circ} \mathrm{C}\end{array}$ & $\begin{array}{l}\text { High biomass solubilisation } \\
\text { High methane yield } \\
\text { increment } \\
\text { Sanitisation of the feedstock }\end{array}$ & $\begin{array}{l}\text { High energy demand } \\
\text { Thickened biomass } \\
\text { Possible recalcitrant } \\
\text { compounds }\end{array}$ & $+4-46 \%$ \\
\hline Chemical & $\begin{array}{l}\text { Adding an alkali or an } \\
\text { acid, usually sodium } \\
\text { peroxide and sulphuric } \\
\text { acid }\end{array}$ & $\begin{array}{l}\text { Low energy demand } \\
\text { Solubilisation of } \\
\text { hemicellulose }\end{array}$ & $\begin{array}{l}\text { Chemical contamination } \\
\text { Chemicals cost } \\
\text { Possible inhibitory compounds } \\
\text { Corrosion problems } \\
\text { Changes of pH in the digester }\end{array}$ & $+37 \%$ \\
\hline
\end{tabular}




\begin{tabular}{lllll} 
& \multicolumn{2}{l}{ Adding an enzyme or } & & Slow process \\
Biological & combination of enzymes & Low energy demand & Big space & $+30-50 \%$ \\
& $\begin{array}{l}\text { to enhancing the } \\
\text { hydrolysis }\end{array}$ & Not inhibitory compounds & Enzyme cost \\
& & Enzyme-substrate specificity \\
\hline
\end{tabular}

\section{Conclusion}

Most pre-treatment techniques can improve biogas production from grass in different percentages around $50 \%[100,111]$. In cases of mechanical methods, the improvement raises to around $60 \%$ $[61,67]$. Mechanical pretreatments lead to a reduction of the particle size of the feedstock which is the best way to improve the availability of the substrate in the case of lignocellulosic materials. Despite that mechanical methods are normally related to high energy requirements, they are still considered very promising, and more research is believed to improve the energy balance for such methods.

Despite the methods' disadvantages, more research is need in order to overcome them and achieve more efficient methods to scale up and applied in industry. High energy requirement is a disadvantage common to all methods; the facilities used for grass pretreatment are machinery pre-existent for other purposes then a deepest study is needed to optimize each appliance for the specific technique where it is used. In chemical and biological treatments, new compounds and enzymes can be studied to increase the effectiveness and at the same time reduce the toxicity and the pre-treatment time. Pretreatment parameters may be specified using multi-objective optimization technique, so that a high biogas yield can be produced with a positive energy balance. Different techniques can be used for solving such multiple response problems. The desirability approach was used in different engineering areas, and it is recommended due to its simplicity, availability in the software and flexibility for each response.

In United Kingdom there are 55 biogas plants working with grass as feedstock from a total of 913 [121,122], grass is always co-digested with other substrates, in most cases alongside with animal slurry. These biogas plants using grass as raw material are in the group of farm-fed plants, farm-fed plants have higher potential of biogas production for the next 3 years with the possibility of reach 500 plants. Pretreatment of grass for biogas production is still not widely used at industrial scale and no information about it could be found for UK.

Most of the member countries of the European Union have drawn up a biogas roadmap as part of their national renewable energy action plan in the framework of the European Renewable Energy Directive (2009/20/EC) [123]. The Directive set the electricity production from biogas in 63.3 TWh by 
2020 that means an increase of $254 \%$ compare to the production in 2009 . This goals are been accomplished, in 2013 the biogas electricity produced in the European Union was 52.3 [124].

In order to study future targets of biogas production from grass for United Kingdom, can be set some key performance indicators (KPIs) which will help us to evaluate the progress in biogas from grass:

- Grass availability

In Northern Ireland, the $5 \%$ of the grassland area (39,000 ha) could contribute $62 \mathrm{MW}$, equivalent to $39 \%$ of the average electricity demand in the region [125]. Considering the similarity of land use in the whole United Kingdom with Northern Ireland, the energy potential from grass could increase to a high extent, especially in Scotland where there is only one biogas plant with grass as raw material.

- Pretreatment method

As was discussed in this paper, pretreatment methods of grass for biogas production improve and accelerate the degradation process achieving higher biogas and methane yields.

- Governmental policies

In UK the government is supporting the role of anaerobic digestion through different plans; the Department for Environment Food \& Rural Affairs (DEFRA) set the level of 305 TWh of heat and electricity from $A D$ by 2020 . Scotland has also introduced food waste bans on disposal to landfill and this has improved the AD capacity. Northern Ireland has introduced four new Renewables Obligation Certificate $(R O C)$ that increases the grass-fed biogas plants [126]. On the EU level, there is no specific policy on biogas, but it is addressed in multiple policy documents and Directives that are related to renewable energies and bioenergy. Biogas is included in three EU regulatory frameworks: the Renewable Energy Directive (2009/28/EC), the Directive on Waste Recycling and Recovery (2008/98/EC) and the Directive on Landfill (1999/31/EC).

\section{References}

[1] Prochnow A, Heiermann M, Plöchl M, Linke B, Idler C, Amon T, et al. Bioenergy from permanent grassland--a review: 1. Biogas. Bioresour Technol 2009;100:4931-44. doi:10.1016/j.biortech.2009.05.070.

[2] FAOSTAT. Agri-Environmental Indicators 2014. http://faostat3.fao.org/browse/E/EL/E (accessed December 8, 2014).

[3] Carlier L, Rotar I, Vlahova M, Vidican R. Importance and Functions of Grasslands. Not Bot Horti Agrobot Cluj-Napoca 2009;37:25-30. 
[4] Scottish Govermnet. Scottish agricultural census 2013.

[5] Olabi AG. The 3rd international conference on sustainable energy and environmental protection SEEP 2009 - Guest Editor's Introduction. Energy 2010;35:4508-9. doi:10.1016/j.energy.2010.09.053.

[6] University of Kentuky. Switchgrass for Bioenergy. 2013.

[7] Rinehart L. Switchgrass as a Bioenergy Crop. 2006.

[8] Smyth BM, Murphy JD, O'Brien CM. What is the energy balance of grass biomethane in Ireland and other temperate northern European climates? Renew Sustain Energy Rev 2009;13:2349-60. doi:10.1016/j.rser.2009.04.003.

[9] IEA Bioenergy. Energy from Biogas. 2014.

[10] Elsäßer M, Messner J, Keymer U, Roßberg R, Setzer F. Biogas from grass: How grassland can contribute to producing energy. Frankfurt Am Main: 2012.

[11] Christoforou E a., Fokaides $P$ a. A Review of Quantification Practices for Plant-Derived Biomass Potential. Int J Green Energy 2014;12:368-78. doi:10.1080/15435075.2014.880147.

[12] Weiland R, Braun P, Wellinger A. Biogas from Energy Crop Digestion. 2010.

[13] Olabi AG. State of the art on renewable and sustainable energy. Energy 2013;61:2-5. doi:10.1016/j.energy.2013.10.013.

[14] Gutierrez E, Caldera Y, Contreras K, Blanco E. Degradación anaerobia mesofilica y termofílica de aguas de producción de petróleo liviano. Bolentin Del Cent Investig Biol Univ Zulia 2006;40:242-56.

[15] Chandra R, Takeuchi H, Hasegawa T. Methane production from lignocellulosic agricultural crop wastes: A review in context to second generation of biofuel production. Renew Sustain Energy Rev 2012;16:1462-76. doi:10.1016/j.rser.2011.11.035.

[16] Nizami A-S, Murphy JD. What type of digester configurations should be employed to produce biomethane from grass silage? Renew Sustain Energy Rev 2010;14:1558-68. doi:10.1016/j.rser.2010.02.006.

[17] Acosta YL, Cristina M, Abreu O. Redalyc.La digestión anaerobia. Aspectos teóricos. Parte I 2005;XXXIX:35-48.

[18] Murphy JD, Thanasit Thamsiriroj. Fundamental science and engineering of the anaerobic digestion process for biogas production. In: Wellinger A, Murphy JP, Baxter D, editors. Biogas Handb., Elsevier; 2013, p. 104-30. doi:10.1533/9780857097415.1.104.

[19] Olabi AG. 100\% sustainable energy. Energy 2014;77:1-5. doi:10.1016/j.energy.2014.10.083.

[20] Naik SN, Goud V V., Rout PK, Dalai AK. Production of first and second generation biofuels: A comprehensive review. Renew Sustain Energy Rev 2010;14:578-97. doi:10.1016/j.rser.2009.10.003.

[21] Hartmann S, Diepolder M, Lichti F. Grünland für die Biogasanlage. 2011.

[22] Seppälä M, Paavola T, Lehtomäki A, Rintala J. Biogas production from boreal herbaceous grasses--specific methane yield and methane yield per hectare. Bioresour Technol 2009;100:2952-8. doi:10.1016/j.biortech.2009.01.044.

[23] Amon T, Amon B, Kryvoruchko V, Zollitsch W, Mayer K, Gruber L. Biogas production from maize and dairy cattle manure-Influence of biomass composition on the methane yield. Agric Ecosyst Environ 2007;118:173-82. doi:10.1016/j.agee.2006.05.007.

[24] Schittenhelm S. Chemical composition and methane yield of maize hybrids with contrasting maturity. Eur J Agron 2008;29:72-9. doi:10.1016/j.eja.2008.04.001.

[25] Smith SR, Schwer L, Keene T, Sena K. Switchgrass for Biomass Production in Kentucky. Lexington: 2011.

[26] Undersander D, Casler M, Cosgrove D. Identifying pasture grasses. Madison, WI: 1996. 
[27] Prochnow A, Heiermann M, Drenckhan A, Schelle H. Seasonal Pattern of Biomethanisation of Grass from Landscape Management. Agric Eng Int CIGR Ejournal 2005;VII.

[28] Keeley JE, Magill FN, editors. C4 and CAM Photosynthetic Pathways. Magill's Surv Sci Life Sci Ser 1991:308-15.

[29] Waller SS, Lewis JK. Occurrence of C 3 and C 4 Photosynthetic Pathways in North American Grasses. J Range Manag 1979;32:12. doi:10.2307/3897378.

[30] The Bioenergy System Planners Handbook - BISYPLAN 2012. http://bisyplan.bioenarea.eu/html-files-en/01-02.html (accessed July 31, 2015).

[31] Murphy J, Braun R, Weiland P, Wellinger A. Biogas from energy crop digestion 2011.

[32] Oleszek M, Król A, Tys J, Matyka M, Kulik M. Comparison of biogas production from wild and cultivated varieties of reed canary grass. Bioresour Technol 2014;156:303-6. doi:10.1016/j.biortech.2014.01.055.

[33] Triolo JM, Pedersen L, Qu H, Sommer SG. Biochemical methane potential and anaerobic biodegradability of non-herbaceous and herbaceous phytomass in biogas production. Bioresour Technol 2012;125:226-32. doi:10.1016/j.biortech.2012.08.079.

[34] Mähnert P, Heiermann M, Linke B. Batch- and Semi-continuous Biogas Production from Different Grass Species. Agric Eng 2005;VII:1-11.

[35] Mähnert P, Heiermann M, Plöchl M, Schelle H, Linke B. Verwertungsalternativen für Grünlandbestände. LANDTECHNIK 2002;5:260-1.

[36] Harmsen P, Huijgen W. Literature Review of Physical and Chemical Pretreatment Processes for Lignocellulosic Biomass. 2010.

[37] Alaswad A, Dassisti M, Prescott T, Olabi AG. Technologies and developments of third generation biofuel production. Renew Sustain Energy Rev 2015;51:1446-60. doi:10.1016/j.rser.2015.07.058.

[38] Rodriguez C, Alaswad A, Mooney J, Prescott T, Olabi AG. Pre-treatment techniques used for anaerobic digestion of algae. Fuel Process Technol 2015;138:765-79. doi:10.1016/j.fuproc.2015.06.027.

[39] Haghighi Mood S, Hossein Golfeshan A, Tabatabaei M, Salehi Jouzani G, Najafi GH, Gholami $\mathrm{M}$, et al. Lignocellulosic biomass to bioethanol, a comprehensive review with a focus on pretreatment. Renew Sustain Energy Rev 2013;27:77-93. doi:10.1016/j.rser.2013.06.033.

[40] Pictures for Lignocellulose structure n.d.

http://www.biofuel.webgarden.com/sections/blog/pictures-for-lignocellulose (accessed May 29, 2015).

[41] Sun Y, Cheng J. Hydrolysis of lignocellulosic materials for ethanol production: a review. Bioresour Technol 2002;83:1-11. doi:10.1016/S0960-8524(01)00212-7.

[42] Agbor VB, Cicek N, Sparling R, Berlin A, Levin DB. Biomass pretreatment: fundamentals toward application. Biotechnol Adv 2011;29:675-85. doi:10.1016/j.biotechadv.2011.05.005.

[43] Kratky L, Jirout T. Biomass Size Reduction Machines for Enhancing Biogas Production. Chem Eng Technol 2011;34:391-9. doi:10.1002/ceat.201000357.

[44] Naimi LJ, Sokhansanj S, Mani S, Hoque M, Bi T. Cost and Performance of Woody Biomass Size Reduction for Energy Production. CSBE/SCGAB 2006 Annu. Conf., Edmonton, Alberta: 2006.

[45] Palmowski LM, Müller JA. Influence of the size reduction of organic waste on their anaerobic digestion. Water Sci Technol 2000;41:155-62.

[46] Tedesco S, Benyounis KY, Olabi a. G. Mechanical pretreatment effects on macroalgaederived biogas production in co-digestion with sludge in Ireland. Energy 2013;61:27-33. doi:10.1016/j.energy.2013.01.071.

[47] Stamatelatou K, Antonopoulou G, Ntaikou I, Lyberatos G. The Effect of Physical, Chemical, 
and Biological Pretreatments of Biomass on its Anaerobic Digestibility and Biogas Production. In: Mudhoo A, editor. Biogas Prod. Pretreat. Methods Anaerob. Dig., Hoboken, NJ, USA: John Wiley \& Sons, Inc.; 2012.

[48] Chang VS, Burr B, Holtzapple MT. Lime pretreatment of switchgrass. Appl Biochem Biotechnol 1997;63-65:3-19. doi:10.1007/BF02920408.

[49] Kobayashi N, Guilin P, Kobayashi J, Hatano S, Itaya Y, Mori S. A new pulverized biomass utilization technology. Powder Technol 2008;180:272-83. doi:10.1016/j.powtec.2007.02.041.

[50] Cadoche L, López GD. Assessment of size reduction as a preliminary step in the production of ethanol from lignocellulosic wastes. Biol Wastes 1989;30:153-7. doi:10.1016/02697483(89)90069-4.

[51] Hideno A, Inoue H, Tsukahara K, Fujimoto S, Minowa T, Inoue S, et al. Wet disk milling pretreatment without sulfuric acid for enzymatic hydrolysis of rice straw. Bioresour Technol 2009;100:2706-11. doi:10.1016/j.biortech.2008.12.057.

[52] Igathinathane C, Womac AR, Miu PI, Yu M, Sokhansanj S, Narayan S. Linear Knife Grid Application for Biomass Size Reduction. ASABE Annu. Meet., Portland: 2006, p. Paper number 066170.

[53] Mani S, Tabil LG, Sokhansanj S. Grinding performance and physical properties of wheat and barley straws, corn stover and switchgrass. Biomass and Bioenergy 2004;27:339-52. doi:10.1016/j.biombioe.2004.03.007.

[54] Ghorbani Z, Masoumi AA, Hemmat A. Specific energy consumption for reducing the size of alfalfa chops using a hammer mill. Biosyst Eng 2010;105:34-40. doi:10.1016/j.biosystemseng.2009.09.006.

[55] Miu PI, Woma AR, Cannayen I, Sokhansanj S. Analysis of Biomass Comminution and Separation Processes in Rotary Equipment. A Review. ASABE Annu. Meet., Portland: 2006, p. Paper number 066169.

[56] Silva GGD, Couturier M, Berrin J-G, Buléon A, Rouau X. Effects of grinding processes on enzymatic degradation of wheat straw. Bioresour Technol 2012;103:192-200. doi:10.1016/j.biortech.2011.09.073.

[57] Bitra VSP, Womac AR, Chevanan N, Miu PI, Igathinathane C, Sokhansanj S, et al. Direct mechanical energy measures of hammer mill comminution of switchgrass, wheat straw, and corn stover and analysis of their particle size distributions. Powder Technol 2009;193:32-45. doi:10.1016/j.powtec.2009.02.010.

[58] Schell DJ, Harwood C. Milling of lignocellulosic biomass. Appl Biochem Biotechnol 1994;4546:159-68. doi:10.1007/BF02941795.

[59] Danish Tech. Inst. Grubben deflaker model GLD 200. 2012.

[60] Cellwood Machinery AB. Krima disperser type KD n.d.

[61] Lindmark J, Leksell N, Schnürer A, Thorin E. Effects of mechanical pre-treatment on the biogas yield from ley crop silage. Appl Energy 2012;97:498-502. doi:10.1016/j.apenergy.2011.12.066.

[62] Menind A, Normak A. Study on Grinding Biomass as Pre-treatment for Biogasification. 2008.

[63] Tsapekos P, Kougias PG, Angelidaki I. Biogas production from ensiled meadow grass; effect of mechanical pretreatments and rapid determination of substrate biodegradability via physicochemical methods. Bioresour Technol 2015;182C:329-35. doi:10.1016/j.biortech.2015.02.025.

[64] Lamsal B, Yoo J, Brijwani K, Alavi S. Extrusion as a thermo-mechanical pre-treatment for lignocellulosic ethanol. Biomass and Bioenergy 2010;34:1703-10. doi:10.1016/j.biombioe.2010.06.009.

[65] Bochmann G, Montgomery LFR. Storage and pre-treatment of substrates for biogas production. Biogas Handb., Elsevier; 2013, p. 85-103. doi:10.1533/9780857097415.1.85. 
[66] Simona M, Gianfranco A, Jody G, Paolo B. Energetic assessment of extrusion as pretreatment to improve the anaerobic digestion of agricultural ligno-cellulosic biomasses n.d.;1.

[67] Hjorth M, Gränitz K, Adamsen APS, Møller HB. Extrusion as a pretreatment to increase biogas production. Bioresour Technol 2011;102:4989-94. doi:10.1016/j.biortech.2010.11.128.

[68] Baltic Compass. Pre-treatment for improved biogas production from meadow grass 2013.

[69] Schwede S, Kowalczyk A, Gerber M, Span R. Influence of different cell disruption techniques on mono digestion of algal biomass. World Renew. Energy Congr., Linköping University Electronic Press; 2011, p. 41-7.

[70] Alzate ME, Muñoz R, Rogalla F, Fdz-Polanco F, Pérez-Elvira SI. Biochemical methane potential of microalgae: influence of substrate to inoculum ratio, biomass concentration and pretreatment. Bioresour Technol 2012;123:488-94. doi:10.1016/j.biortech.2012.06.113.

[71] Kim J, Yoo G, Lee H, Lim J, Kim K, Kim CW, et al. Methods of downstream processing for the production of biodiesel from microalgae. Biotechnol Adv 2013;31:862-76. doi:10.1016/j.biotechadv.2013.04.006.

[72] Martinez-Guerra E, Gude VG, Mondala A, Holmes W, Hernandez R. Microwave and ultrasound enhanced extractive-transesterification of algal lipids. Appl Energy 2014;129:35463. doi:10.1016/j.apenergy.2014.04.112.

[73] Imai M, Ikari K, Suzuki I. High-performance hydrolysis of cellulose using mixed cellulase species and ultrasonication pretreatment. Biochem Eng J 2004;17:79-83. doi:10.1016/S1369703X(03)00141-4.

[74] Samson R, Leduy A. Influence of mechanical and thermochemical pretreatments on anaerobic digestion ofSpirulina maxima algal biomass. Biotechnol Lett 1983;5:671-6. doi:10.1007/BF01386360.

[75] González-Fernández C, Sialve B, Bernet N, Steyer JP. Comparison of ultrasound and thermal pretreatment of Scenedesmus biomass on methane production. Bioresour Technol 2012;110:610-6. doi:10.1016/j.biortech.2012.01.043.

[76] Braeutigam P, Franke M, Ondruschka B. Effect of ultrasound amplitude and reaction time on the anaerobic fermentation of chicken manure for biogas production. Biomass and Bioenergy 2014;63:109-13. doi:10.1016/j.biombioe.2014.02.007.

[77] Braguglia CM, Gagliano MC, Rossetti S. High frequency ultrasound pretreatment for sludge anaerobic digestion: effect on floc structure and microbial population. Bioresour Technol 2012;110:43-9. doi:10.1016/j.biortech.2012.01.074.

[78] Castrillón L, Fernández-Nava Y, Ormaechea P, Marañón E. Optimization of biogas production from cattle manure by pre-treatment with ultrasound and co-digestion with crude glycerin. Bioresour Technol 2011;102:7845-9. doi:10.1016/j.biortech.2011.05.047.

[79] Gallipoli A, Gianico A, Gagliano MC, Braguglia CM. Potential of high-frequency ultrasounds to improve sludge anaerobic conversion and surfactants removal at different food/inoculum ratio. Bioresour Technol 2014;159:207-14. doi:10.1016/j.biortech.2014.02.084.

[80] Ahamed N. Ultrasonic pretreatment of energy cane bagasse for biofuel production. Louisiana State University, 2014.

[81] Patil P, Reddy H, Muppaneni T, Ponnusamy S, Sun Y, Dailey P, et al. Optimization of microwave-enhanced methanolysis of algal biomass to biodiesel under temperature controlled conditions. Bioresour Technol 2013;137:278-85. doi:10.1016/j.biortech.2013.03.118.

[82] Passos F, Solé M, García J, Ferrer I. Biogas production from microalgae grown in wastewater: Effect of microwave pretreatment. Appl Energy 2013;108:168-75. doi:10.1016/j.apenergy.2013.02.042.

[83] Tyagi VK, Lo S-L. Microwave irradiation: A sustainable way for sludge treatment and resource recovery. Renew Sustain Energy Rev 2013;18:288-305. doi:10.1016/j.rser.2012.10.032.

[84] CMF. Techcommentary: Industial microwave heating applications 1993;4. 
[85] Eskicioglu C, Kennedy KJ, Droste RL. Enhanced disinfection and methane production from sewage sludge by microwave irradiation. Desalination 2009;248:279-85. doi:10.1016/j.desal.2008.05.066.

[86] Kuglarz M, Karakashev D, Angelidaki I. Microwave and thermal pretreatment as methods for increasing the biogas potential of secondary sludge from municipal wastewater treatment plants. Bioresour Technol 2013;134:290-7. doi:10.1016/j.biortech.2013.02.001.

[87] Sapci Z. The effect of microwave pretreatment on biogas production from agricultural straws. Bioresour Technol 2013;128:487-94. doi:10.1016/j.biortech.2012.09.094.

[88] Banik S, Bandyopadhyay S, Ganguly S, Dan D. Effect of microwave irradiated Methanosarcina barkeri DSM-804 on biomethanation. Bioresour Technol 2006;97:819-23. doi:10.1016/j.biortech.2005.04.032.

[89] Li L, Kong X, Yang F, Li D, Yuan Z, Sun Y. Biogas production potential and kinetics of microwave and conventional thermal pretreatment of grass. Appl Biochem Biotechnol 2012;166:1183-91. doi:10.1007/s12010-011-9503-9.

[90] Jackowiak D, Frigon JC, Ribeiro T, Pauss A, Guiot S. Enhancing solubilisation and methane production kinetic of switchgrass by microwave pretreatment. Bioresour Technol 2011;102:3535-40. doi:10.1016/j.biortech.2010.11.069.

[91] Carrère H, Dumas C, Battimelli A, Batstone DJ, Delgenès JP, Steyer JP, et al. Pretreatment methods to improve sludge anaerobic degradability: a review. J Hazard Mater 2010;183:1-15. doi:10.1016/j.jhazmat.2010.06.129.

[92] Menardo S, Airoldi G, Balsari P. The effect of particle size and thermal pre-treatment on the methane yield of four agricultural by-products. Bioresour Technol 2012;104:708-14. doi:10.1016/j.biortech.2011.10.061.

[93] Bohutskyi P, Bouwer E. Biogas Production from Algae and Cyanobacteria Through Anaerobic Digestion. A Review, Analysis, and Research Needs. In: Lee JW, editor. Adv. Biofuels Bioprod. Vol 1, New York, NY: Springer New York; 2013, p. 873-975. doi:10.1007/978-1-46143348-4.

[94] Montgomery LFR, Bochmann G. Pretreatment of feedstock for enhanced biogas production. Tulln, Austria: 2014.

[95] Fernández-Cegrí V, Angeles De la Rubia M, Raposo F, Borja R. Effect of hydrothermal pretreatment of sunflower oil cake on biomethane potential focusing on fibre composition. Bioresour Technol 2012;123:424-9. doi:10.1016/j.biortech.2012.07.111.

[96] Ziemiński K, Romanowska I, Kowalska-Wentel M, Cyran M. Effects of hydrothermal pretreatment of sugar beet pulp for methane production. Bioresour Technol 2014;166:187-93. doi:10.1016/j.biortech.2014.05.021.

[97] López González LM, Pereda Reyes I, Dewulf J, Budde J, Heiermann M, Vervaeren H. Effect of liquid hot water pre-treatment on sugarcane press mud methane yield. Bioresour Technol 2014;169:284-90. doi:10.1016/j.biortech.2014.06.107.

[98] Bohutskyi P, Betenbaugh MJ, Bouwer EJ. The effects of alternative pretreatment strategies on anaerobic digestion and methane production from different algal strains. Bioresour Technol 2014;155:366-72. doi:10.1016/j.biortech.2013.12.095.

[99] Bauer A, Lizasoain J, Theuretzbacher F, Agger JW, Rincón M, Menardo S, et al. Steam explosion pretreatment for enhancing biogas production of late harvested hay. Bioresour Technol 2014;166:403-10. doi:10.1016/j.biortech.2014.05.025.

[100] Wang F, Hidaka T, Tsumori J. Enhancement of anaerobic digestion of shredded grass by codigestion with sewage sludge and hyperthermophilic pretreatment. Bioresour Technol 2014;169:299-306. doi:10.1016/j.biortech.2014.06.053.

[101] General Biomass. General Biomass 2013. http://www.generalbiomass.com/cellethanol1.htm (accessed July 31, 2015).

[102] Mendez L, Mahdy A, Timmers RA, Ballesteros M, González-Fernández C. Enhancing 
methane production of Chlorella vulgaris via thermochemical pretreatments. Bioresour Technol 2013;149:136-41. doi:10.1016/j.biortech.2013.08.136.

[103] Cho S, Park S, Seon J, Yu J, Lee T. Evaluation of thermal, ultrasonic and alkali pretreatments on mixed-microalgal biomass to enhance anaerobic methane production. Bioresour Technol 2013;143:330-6. doi:10.1016/j.biortech.2013.06.017.

[104] Behera S, Arora R, Nandhagopal N, Kumar S. Importance of chemical pretreatment for bioconversion of lignocellulosic biomass. Renew Sustain Energy Rev 2014;36:91-106. doi:10.1016/j.rser.2014.04.047.

[105] Lope Tabil PA and MK. Biomass Feedstock Pre-Processing - Part 1: Pre-Treatment. In: Dos Santos Bernardes MA, editor. Biofuel's Eng. Process Technol., InTech; 2011, p. 411-38. doi:10.5772/961.

[106] Zheng Y, Zhao J, Xu F, Li Y. Pretreatment of lignocellulosic biomass for enhanced biogas production. Prog Energy Combust Sci 2014;42:35-53. doi:10.1016/j.pecs.2014.01.001.

[107] Khor WC, Rabaey K, Vervaeren H. Low temperature calcium hydroxide treatment enhances anaerobic methane production from (extruded) biomass. Bioresour Technol 2015;176:181-8. doi:10.1016/j.biortech.2014.11.037.

[108] Kiril Mert B, Yonar T, Yalili Kiliç M, Kestioğlu K. Pre-treatment studies on olive oil mill effluent using physicochemical, Fenton and Fenton-like oxidations processes. J Hazard Mater 2010;174:122-8. doi:10.1016/j.jhazmat.2009.09.025.

[109] Michalska K, Miazek K, Krzystek L, Ledakowicz S. Influence of pretreatment with Fenton's reagent on biogas production and methane yield from lignocellulosic biomass. Bioresour Technol 2012;119:72-8. doi:10.1016/j.biortech.2012.05.105.

[110] Kumar P, Barrett DM, Delwiche MJ, Stroeve P. Methods for Pretreatment of Lignocellulosic Biomass for Efficient Hydrolysis and Biofuel Production. Ind Eng Chem Res 2009;48:3713-29. doi:10.1021/ie801542g.

[111] Wen B, Yuan X, Li QX, Liu J, Ren J, Wang X, et al. Comparison and evaluation of concurrent saccharification and anaerobic digestion of Napier grass after pretreatment by three microbial consortia. Bioresour Technol 2014. doi:10.1016/j.biortech.2014.10.043.

[112] López MJ, Suárez-Estrella F, Vargas-García MC, López-González JA, Verstichel S, Debeer L, et al. Biodelignification of agricultural and forest wastes: Effect on anaerobic digestion. Biomass and Bioenergy 2013;58:343-9. doi:10.1016/j.biombioe.2013.10.021.

[113] Dewar WA, McDonald P, Whittenbury R. The hydrolysis of grass hemicelluloses during ensilage. J Sci Food Agric 1963;14:411-7. doi:10.1002/jsfa.2740140610.

[114] Buxton DR, Muck RE. Silage science and technology. Madison, WI : American Society of Agronomy; 2003.

[115] Sieker T, Neuner A, Dimitrova D, Tippkötter N, Muffler K, Bart H-J, et al. Ethanol production from grass silage by simultaneous pretreatment, saccharification and fermentation: First steps in the process development. Eng Life Sci 2011;11:436-42. doi:10.1002/elsc.201000160.

[116] Ambye-Jensen M, Johansen KS, Didion T, Kádár Z, Schmidt JE, Meyer AS. Ensiling as biological pretreatment of grass (Festulolium Hykor): The effect of composition, dry matter, and inocula on cellulose convertibility. Biomass and Bioenergy 2013;58:303-12. doi:10.1016/j.biombioe.2013.08.015.

[117] Bywater A. A Review of Anaerobic Digestion Plants on UK Farms. Warwickshire: n.d.

[118] European Biogas Association, MT-Energie. Waste to Energy in England. Brussels, Belgium: 2013.

[119] European Biogas Association. The first biomethane plant running on hop silage in Oberlauterbach-Hallertau, Germany. Brussels, Belgium: 2013.

[120] DSM Biogas, Association EB. Driving efficiency improvements through MethaPlus $\AA$ L100 enzyme. Brussels, Belgium: 2013. 
[121] The National Non-Food Crops Centre. Official UK Biogas Map n.d. http://www.biogasinfo.co.uk/.

[122] Lukehurst CT. UK Country Report. Berlin (Germany): 2015.

[123] EBA - European Biogas Association. Biogas. Simply the best. Brussels, Belgium: 2011.

[124] EurObserv'ER. Biogas Barometer. 2014.

[125] Groom E, Orozco A. Northen Ireland. Biogas Research Action Plan 2020. Belfast: 2014.

[126] The National Non-Food Crops Centre. Incentives. Anaerobic Digestion 2016. http://www.biogas-info.co.uk/about/incentives/ (accessed January 27, 2016). 